\title{
Artikkeli
}

\section{Viestintää teknologian välityksellä asiantuntijaverkostoissa}

Työelämän toimintaympäristöjen muutokset haastavat asiantuntijoiden viestintäosaamisen. Verkostomainen kansainvälinen toiminta ja digitaalisuus ovat johtaneet tilanteeseen, jossa on selkeytettävä, miten teknologian välityksellä viestitään ja millaista osaamista teknologiavälitteinen viestintä vaatii. Teknologiavälitteistä viestintäosaamista lähestytään tässä tutkimuksessa digitaalisen osaamisen viitekehyksen avulla huomioiden myös viestintään liittyvät eettiset tekijät (Ferrari 2013). Tutkimus vastaa seuraaviin kysymyksiin: Mitä viestintäkanavia viestintään käytetään? Mitä osaamista näillä viestiminen vaatii? Mitä teknologiavälitteisen viestintäosaamisen alueita työelämässä tulisi kehittää? Tutkimuksen aineisto on kerätty kyselylomakkeella ( $\mathrm{N}=98)$. Tutkimuksen mukaan asiantuntijatyössä yksikään teknologivälitteisen viestinnän osa-alueista ei yllä edellytetylle osaamistasolle. Osaamiskuilu ei ole kuitenkaan suuri, mutta tulosten mukaan uhkakuvana on sen suureneminen etenkin asiantuntijatehtävissä, joissa vuorovaikutus eri kulttuurien välillä ja verkostomaisuus lisääntyvät. Asiantuntijoilta edellytetään entistä enemmän viestintäosaamista ja ennen kaikkea eettisen toiminnan ymmärtämistä teknologian välityksellä viestittäessä.

AVAINSANAT: viestintä, viestintäteknologia, asiantuntija, viestintäosaaminen, digitalisaatio

$\mathrm{V}$ iime vuosikymmenten aikana globalisaatio ja teknologian kehittyminen ovat olennaisesti muuttaneet asiantuntijoiden toimintaympäristöjä. Töitä tehdään monissa eri ympäristöissä ja hajautettu, virtuaalinen yhteistyö on lisääntynyt teknologian mahdollistaessa vuorovaikutuksen ajasta ja paikasta riippumatta (Lönnblad \& Vartiainen 2012). Jatkuvat muutokset, epävarmuus ja kompleksisuus ilmentävät näitä työnteon ympäristöjä, joissa toimiakseen asiantuntijoiden tulee tehdä 
yhteistyötä ja verkostoitua. Verkostoissa tiedon, sosiaalisuuden ja viestinnän merkitys korostuu entisestään (Julkunen 2008). Viestintä onkin tunnistettu yhdeksi organisaatioiden olemassaolon peruspilariksi (Kleinbaum ym. 2008; Wrench 2013, 9). Samalla kun teknologian merkitys viestinnässä kasvaa, käsitys viestintäosaamisesta asiantuntijatehtävissä muuttuu. Asiantuntijoiden tulee osata käyttää teknologiaa viestintään, viestiä vierailla kielillä ja ymmärtää kulttuurienvälisiä erilaisuuksia (Huhta 2010; Lönnblad \& Vartiainen 2012; Ladegaard \& Jenks 2015).

Tämän artikkelin kontribuutio on siinä, että viestintää ja erityisesti viestintäosaamista tarkastellaan teknologiavälitteisyyden ja asiantuntijatehtävien näkökulmista. Näkökulma on merkittävä, sillä suomalaisesta työvoimasta lähes $40 \%$ toimii asiantuntijatehtävissä, ja määrän ennustetaan edelleen kasvavan (Tilastokeskus 2015). Asiantuntijalla tarkoitetaan tässä tutkimuksessa laajasti henkilöä, jolla on vahva teoreettinen ymmärrys ja käytännön taidot tietyssä asiassa ja joka pystyy kehittämään osaamistaan ja toimimaan sosiaalisissa verkostoissa (esim. Tynjälä 2010; Palonen ym. 2014). Asiantuntijalla ei siis viitata tässä työntekijäkategorioihin.

Viestintä ymmärretään tässä tutkimuksessa vuorovaikutussuhteena yksilöiden ja yhteisöjen välillä toimintaympäristöissä, joissa viestintäteknologialla on suuri merkitys viestinnän tarkoituksenmukaisuuden toteutumiseen. Vaikka jotkut tutkijat näkevät viestintä- ja vuorovaikutusosaamisen erillisinä käsitteinä, tässä ne ymmärretään rinnakkaisina ja siksi osaamiseen viitataan jatkossa käsitteellä viestintäosaaminen (Laajalahti 2014, 17). Viestintäosaaminen sisältää puhumisen, kuuntelemisen, kirjoittamisen ja lukemisen sekä median käytön (Valkonen 2003, 25-26). Viestintäosaamisen nähdään kuuluvan jokaisen työntekijän ammattiosaamiseen, ja se ilmenee viestinnällisenä toimintakykynä sekä tietona, taitoina ja asenteena omissa työtehtävissä (Youell \& Downey 2000; Kostiainen 2003). Tämä tarkoittaa, että asiantuntijalla on tietoa siitä, miten eri viestintätilanteissa on tarkoituksenmukaista toimia, ja hän tiedostaa viestinnän myös osana organisaationsa toimintaa (Huhta 2013). Tämän tiedon pohjalta hän osaa käyttäytyä tarkoituksenmukaisesti eri viestintätilanteissa. Tietojen ja taitojen lisäksi olennaista on asenne eli motivaatio ja rohkeus viestiä tarkoituksenmukaisesti. Viestintään liittyy myös eettinen ulottuvuus, joka tarkoittaa tarkoituksenmukaista sekä hyväksyttävää toimintaa, rehellisyyttä, vilpittömyyttä ja muiden kunnioittamista eri viestintätilanteissa. (Spitzberg \& Cupach 2002, 583; Valkonen 2003, 26-39.) Kun viestitään teknologian välityksellä, myös näkemykset turvallisuudesta, lähdekritiikistä, omasta digitaalisesta profiilista ja oman organisaation verkossa toimimisen pelisäännöistä ovat merkityksellisiä (Ferrari 2013). Tarkasteltaessa verkossa viestimisen mahdollisia negatiivisia vaikutuksia yksilöön, työnantajaorganisaatioon tai sidosryhmiin, puhutaan verkossa toimimisen riskeistä.

Tämän artikkelin teoreettisen kokonaisuuden muodostaa teknologiavälitteisen viestintäosaamisen käsite, joka koostuu edellä kuvatusta viestintäosaamisesta sekä siihen liittyvästä eettisestä osaamisesta. Empiirisessä osiossa analysoidaan Suomessa tehdyn kyselytutkimuksen aineistoa $(\mathrm{N}=98)$ ja esitetään vastaukset tutkimuskysymyksiin: Mitä viestintäkanavia viestintään käytetään? Mitä osaamista näillä 
viestiminen vaatii? Mitä teknologiavälitteisen viestintäosaamisen alueita työelämässä tulisi kehittää? Tuloksia voidaan hyödyntää erityisesti työelämän osaamisen kehittämisen toimenpiteissä sekä korkeakoulujen opetussuunnitelmatyössä.

\section{Yksisuuntaisesta viestinnästä verkostoissa viestimiseen}

Maailman muuttuessa käsitykset viestinnästä ovat muuttuneet radikaalisti. Raja sisäisen ja ulkoisen viestinnän välillä on hämärtynyt ja puhutaan mieluummin viestinnästä verkostoissa, joissa hiljaisesta tiedosta muodostetaan näkyvää (Gruber ym. 2008). Esimerkiksi palvelujen tarjoamiseen kuluttajille voidaan käyttää virtuaalisen vuorovaikutuksen mahdollistavia palveluja, kuten Facebookia (Varpelaide 2013, 38-39). Palveluja ei kuitenkaan vain tarjota kuluttajille, vaan niitä tuotetaan verkostomaisesti monen toimijan yhteistyönä. Virtuaalisesta vuorovaikutuksesta sidosryhmien kanssa tuleekin yhä enemmän osa organisaation viestintää (Waters \& Lemanski 2011).

Väistämättä myös asiantuntijoiden toimintaympäristöissä ryhmä- ja tiimityö korostuvat entisestään ja asiantuntijuudesta tulee kollektiivista ja verkostoitunutta (Hakkarainen ym. 2011; Rubin 2012; Hakkarainen ym. 2012). Myös monikulttuurisuus ja vieraalla kielellä viestiminen ovat tyypillisiä näille toimintaympäristöille (Lönnblad \& Vartiainen 2012; Ladegaard \& Jenks 2015). Verkostoitumista vauhdittaa sekin, että tiedon määrä on nykyään niin valtava, eikä asiantuntija voi hallita kaikkea tietoa yksin, etenkään, kun asiantuntijuuteen ei jatkossa riitä perinteinen oman alan osaaminen vaan asiantuntijuus on yhä monialaisempaa (Palonen ym. 2014). Tiedosta on tullut yksi työelämän tärkeimmistä kilpailueduista ja olennaiseksi nouseekin se, miten tietoa osataan käyttää, prosessoida ja jakaa eteenpäin (Ek \& Niemelä 2010). Merkittävä osa hiljaisen tiedon näkyväksi tekemisessä ja uuden tiedon luomisessa on vuorovaikutuksella, jota verkoston jäsenet käyvät keskenään (Nonaka \& Takeuchi 2004; Alasoini ym. 2012, 29). Tätä hajautuneen tiedon hyödyntämistä voidaan lisätä huomattavasti käyttämällä uudenlaista teknologiaa viestintään (Jussila 2015).

\section{Näkemyksiä teknologiavälitteisestä viestinnästä}

Toimintaympäristöjen muutoksissa oma roolinsa on viestintäteknologian kehittymisellä (Lipnack \& Stamps 2000; Berry 2011, 186-187). Teknologiavälitteinen viestintä ${ }^{1}$ on viestintää teknologian, esimerkiksi sähköpostin tai sosiaalisen median palvelujen, avulla. Tässä viestinnässä välittyvät kuvat, äänet, videot, tekstit. (Veltsos \& Veltsos 2010, 463.) Viestintä voi olla samanaikaista eli synkronista, jolloin viestintä tapahtuu osapuolten ollessa läsnä samaan aikaan esimerkiksi pikaviestimien avulla. Eriaikaista eli asynkronista viestintä on silloin, kun osapuolet eivät ole läsnä samaan aikaan vaan viestivät esimerkiksi sähköpostiviestein. Kyse on siis viestin viiveen erilaisuudesta. (Romiszowski \& Mason 2004; Sivunen 2007, 30.) Teknologiavälitteisen 
viestinnän suurimpia lisäarvoja onkin, että se mahdollistaa paikasta ja ajasta riippumattoman viestinnän (Rockinson-Szapkiw ym. 2010, 164) sekä sähköisen sisällön jakamisen.

Organisaatioissa teknologiavälitteistä viestintää voidaan katsoa muun muassa viestintävälineen tai sosiaalisen toiminnan näkökulmista. Välinenäkökulmaan liittyy usein ajatus siitä, että viestintä on tehokkaampaa kasvotusten kuin viestintäkanavia hyödyntäen (Koskela ym. 2007, 126; Lockwood 2014). Vanhimpia ja tutkimuksissa käytetyimpiä teknologivälitteisen viestinnän teorioita on median monipuolisuuden teoria (Media Richness Theory), jonka kehittäjät esittävät, että sosiaaliset vihjeet, kuten eleet, tunteet ja ilmeet välittyvät heikosti teknologian välityksellä viestittäessä, mikä vaikuttaa teknologian kykyyn välittää informaatiota (Daft \& Lengel 1986). Teknologia on kuitenkin kehittynyt paljon 80-luvulta ja nykyajan tutkimus tarkastelee teknologivälitteistä viestintää myös sosiaalisena vuorovaikutuksena ja verkostoitumisena (Tidwell \& Walther 2002; Lönnblad \& Vartiainen 2012; Hansen 2015). Tässä vuorovaikutuksessa alati kehittyvä viestintäteknologia mahdollistaa uusien vihjeiden välittämisen yhä monipuolisemmin (Walther 2012) esimerkiksi hymiöiden avulla. Vihjeiden lisäksi tarkastellaan itse viestintäprosessia ja viestintäkanavien eri ominaisuuksien hyödyntämistä viestintätilanteissa. Median synkronisuuden teoria (Media Synchronicity Theory) esittää, että viestintäkanavien eri ominaisuuksia ovat nopeus, tallentamisen mahdollisuus, viestien rinnakkaisuus, symbolien käyttö ja viestin uudelleen muokattavuus. Kuhunkin viestintäprosessiin käytetään siihen sopivia välineitä ja niiden ominaisuuksia. (Dennis ym. 2008, 581-587.) Teknologiavälitteisen viestinnän nähdäänkin tänä päivänä vastaavan monissa tilanteissa kasvokkaisviestintää ( $\mathrm{mm}$. Tidwell \& Walther 2002,Twine \& Brown 2011). Esimerkiksi mitä pidempään jokin ryhmä työskentelee yhdessä teknologian välityksellä, sitä enemmän tämä viestintä vastaa kasvokkain viestintää (Tidwell \& Walther 2002). Sosiaalisissa tilanteissa teknologiavälitteinen viestintä voi joistakin yksilöistä tuntua jopa paremmalta kuin kasvokkaisviestintä, sillä teknologian välityksellä viestittäessä voi esimerkiksi vaikuttaa siihen, minkälaisen kuvan itsestään haluaa vastapuolelle antaa (Walther 1996; 2006).

On ilmeistä, että viestintäteknologia, sen mahdollistamat erilaiset vihjeet ja viiveet sekä vuorovaikutusnäkökulma ovat tehneet mahdolliseksi asiantuntijoiden viestimisen monikulttuurisissa verkostoissa (Lönnblad \& Vartiainen 2012; Klitmøller \& Lauring 2013). Monikulttuurisuus tuo uusia ulottuvuuksia asiantuntijaviestintään. Tutkimukset osoittavat, että kulttuurisidonnaiset toimintatavat voivat vaikeuttaa tiedon jakamista monikulttuurisissa tiimeissä, kun kyseessä on monimutkainen asia (Stahl ym. 2010). Jos monimutkaisen idean esittämisessä käytetään sähköpostia, se saattaa aiheuttaa väärinymmärryksiä ja viestintäkatkoksia. Toisaalta sähköpostin käyttöä voidaan puoltaa sen eriaikaisuudella. Etenkin vieraalla kielellä monimutkaisista asioista viestittäessä sähköposti antaa mahdollisuuden pohtia tarkemmin, miten viestiä vieraalla kielellä vieraan kulttuurin edustajan kanssa. Sähköposti mahdollistaa myös kieliasun tarkistuksen. (Klitmøller \& Lauring 2013.) Hansen ym. (2015) 
esittävät, että sosiaalisessa vuorovaikutuksessa vihjeiden vähyydellä voi olla hyvätkin puolensa, sillä se voi estää vastapuolen arvostelua esimerkiksi kulttuuritaustan vuoksi (Hansen ym. 2015).

Edellä kuvattuja tutkimuksia ja näkemyksiä teknologivälitteisestä viestinnästä, sen tehokkuudesta ja vihjeiden vaikutuksesta siihen on useita. Viestinnän alati muuttuessa nämä lukuisat näkemykset, jotka tarkastelevat teknologiavälitteistä viestintää yksilön ja sosiaalisten verkostojen näkökulmista tullevat sulautumaan (Spitzberg 2015).

\section{Teknologiavälitteisen viestinnän kahdet kasvot}

Teknologiavälitteisen viestinnän tutkimus on ollut suurta ja monitahoista ja uusia kysymyksiä nousee jatkuvasti (Walther 2012; Spitzberg 2015). Erityisesti erilaiset haasteet ja eettiset näkökulmat ovat nousseet keskusteluihin työelämässä. Esimerkiksi työnantajaorganisaation ajattelutavat ja työntekijän ajattelutavat saattavat poiketa toisistaan ja aiheuttaa työntekijän turhautumista. Työnantajan edellyttäessä tehokasta ja sääntöjen mukaista viestintää virtuaalisissa ympäristöissä, voi työntekijällä ammatillisesta näkökulmasta, vastoin työnantajan odotuksia, olla mielenkiintoa liittyä julkisiin käytännön keskusteluihin jakaakseen tietoa ja lisätäkseen omaa mainettaan. (Oostervink ym. 2016.) Ajattelutapojen ristitulessa saattaa työntekijä välttää kriittistä julkista keskustelua pitääkseen mainettaan yllä omassa työyhteisössään (Majchrzak ym. 2013; Oostervink ym. 2016, 170). Edellä mainitun lisäksi keskusteluissa tulee esiin yksityisyys. Monet pohtivat, valvotaanko työntekijöiden viestintää verkossa, jaetaanko heidän tietojaan eteenpäin ja voiko tietoverkkojen turvallisuuteen luottaa. (Tamminen ym. 2011, 232.) Epätietoisuus voi johtaa ideoinnin ja innovoinnin vähenemiseen organisaatioissa.

Työyhteisöissä henkilöstöä puhuttaa myös rajanveto työ- ja vapaa-ajan välillä. Etenkin internet, sähköposti ja mobiilit laitteet hämärtävät työnteon ja vapaa-ajan rajaa, koska ne tarjoavat pääsyn työtehtäviin liittyviin asioihin ympäri vuorokauden. Kuormitusta työssä pyritään helpottamaan työskentelemällä illalla kotona (Ojala \& Pyöriä 2013). Joidenkin tutkimusten mukaan runsas sähköpostin määrä jo työaikanakin aiheuttaa stressiä työntekijöille (Mark ym. 2014; Kushlev \& Dunn 2015). Tähän rajanvetoon liittyy autonomian paradoksi (autonomy paradox). Kun työntekijällä on mahdollisuus tehdä töitä missä ja milloin vain joustavasti, esimerkiksi sähköpostin välityksellä, se lisää muiden oletuksia siitä, että kyseinen henkilö on aina tavoitettavissa sähköpostitse. Tämä osaltaan aiheuttaa kierteen, jossa työntekijä ei katso voivansa irtautua työstä. (Mazmanian ym. 2013.)

Verkossa toimimisen käyttäytymissääntöjen soveltaminen nousee yhä tärkeämmäksi osaamisalueeksi työyhteisöissä, ja mielenkiintoista on, että erityisesti naiset ovat huolissaan riskeistä, joita on esimerkiksi internetissä viestimisessä (Youn \& Hall 2008; Hoy \& Milne 2010; Smit 2014). Treemin ym. $(2015,419)$ mukaan kokemukset vapaa-ajalla käytetystä teknologiasta vaikuttavat näkemyksiin työtehtävissä käyte- 
tyistä viestintäkanavista. Tutkimusten mukaan naiset käyttävät miehiä enemmän verkostoitumispalveluja, videopuheluja sekä tekstipohjaisia palveluja vuorovaikutukseen (Kimbrough ym. 2013). Tällä saattaa olla merkitystä siihen, että naiset pohtivat verkossa viestimisen riskejä miehiä enemmän.

Työyhteisöissä pohditaan usein osaamiseroja myös sukupolvien välillä. Nuorempaa sukupolvea pidetään taitavana ja innokkaana viestintäteknologian hyödyntäjänä ja tämän osaamisen ja innokkuuden uskotaan siirtyvän vapaa-ajalta työelämään (Cummings 2013; Treem ym. 2015, 401), mutta viestintään liittyvät haasteet saattavat jäädä huomiotta. Esimerkiksi nuoremmalle työelämään astuvalle sukupolvelle, joka on tottunut vapaasti ilmaisemaan itseään sosiaalisessa mediassa, ei aina ole selvää, mitä ja miten yrityksen nimissä verkossa voi keskustella (Williams ym. 2012; Treem ym. 2015, 401). Erimielisyyksiä saattaa aiheuttaa sekin, että nuorilla voi olla erilainen näkemys kuin vanhemmilla työntekijöillä siitä, miten teknologiavälitteinen viestintä voisi tukea yrityksen toimintoja ja tuottavuutta (Myers \& Sadaghiani 2010, 235).

\section{Teknologiavälitteinen viestintäosaaminen korostuu asiantuntijaverkostoissa}

Tässä artikkelissa teknologiavälitteistä viestintäosaamista tarkastellaan digitaalisen osaamisen viitekehyksen avulla (DigComp, Ferrari 2013). Tähän viitekehykseen kuuluu digitaalisen osaamisen itsearviointitaulukko, joka on jaettu viiteen pääalueeseen: osaamiset liittyen tietoon, sisällön luomiseen, turvallisuuteen, ongelmanratkaisuun sekä tämän tutkimuksen kannalta mielenkiintoisimpaan osaamisalueeseen eli teknologiavälitteiseen viestintään. Viitekehys valittiin, sillä se kuvaa teknologiavälitteistä viestintäosaamista sekä oppimisen että työelämän toimintaympäristöissä. Se on yksi uusimmista malleista, eikä tutkimustietoa sen soveltuvuudesta teknologiavälitteisen viestintäosaamisen arviointiin ole saatavilla. Mielenkiintoisen viitekehyksestä tekee se, että se on kehitetty Euroopan komission yhteisessä tutkimuskeskuksessa (Joint Research (entre - JRC) tukemaan digitaalisten osaamisten kehittämistä Euroopassa. Viitekehyksen vahvuutta kuvaa se, että sen kehittämisessä on yhdistetty useita aiempia viitekehyksiä ( $n=15)$ ja hyödynnetty erittäin vahvaa työelämäyhteistyötä. Työelämäyhteistyö on toteutunut muun muassa online-konsultaatioissa ( $n=95)$ sekä asiantuntijatyöpajoissa. teknologiavälitteisen viestintäosaamisen itsearviointitaulukko esitetään taulukossa 1. Taulukossa osaaminen on kuvattu kolmella eri osaamistasolla, joista taso A vastaa perustasoa, taso B keskitasoa ja taso C edistynyttä tasoa. (ks. Ferrari 2013.) 
Taulukko 1. Teknologiavälitteisen viestintäosaamisen itsearviointitaulukko (suomennettu Ferrarin [2013] mukaan).

\begin{tabular}{|c|c|c|c|}
\hline $\begin{array}{l}\text { Teknologiavälitteisen } \\
\text { viestinnän osa-alueet }\end{array}$ & Perustaso A & Keskitaso B & Edistynyt taso C \\
\hline $\begin{array}{l}\text { Vuorovaikutus tekno- } \\
\text { logioiden avulla (inter- } \\
\text { acting through techno- } \\
\text { logies) } \\
\text { Tiedon ja sisällön jaka- } \\
\text { minen (sharing infor- } \\
\text { mation and content) } \\
\text { Verkkokansalaisuus } \\
\text { (engaging in online } \\
\text { citizeship) } \\
\text { Yhteistyö digitaalisis- } \\
\text { sa kanavissa (collabo- } \\
\text { rating through digital } \\
\text { channels) } \\
\text { Verkkoviestinnän } \\
\text { käyttäytymissäännöt } \\
\text { (netiquette) } \\
\text { Digitaalisen henkilölli- } \\
\text { syyden hallinta (mana- } \\
\text { ging digital identity) }\end{array}$ & $\begin{array}{l}\text { Osaan pitää yhteyttä } \\
\text { muihin käyttämäl- } \\
\text { lä viestintäkanavien } \\
\text { perusominaisuuksia. } \\
\text { Tunnen digitaalista } \\
\text { viestintää koskevat } \\
\text { käyttäytymisen pe- } \\
\text { russäännöt. Osaan } \\
\text { jakaa tiedostoja ja si- } \\
\text { sältöä muiden kanssa } \\
\text { yksinkertaisilla tek- } \\
\text { nologisilla välineillä. } \\
\text { Tiedän, että teknolo- } \\
\text { gian avulla voidaan } \\
\text { käyttää erilaisia } \\
\text { palveluita, ja käytän } \\
\text { joitakin passiivisesti. } \\
\text { Osaaan tehdä yhteis- } \\
\text { työtä muiden kanssa } \\
\text { perinteisten teknolo- } \\
\text { gioiden avulla. Olen } \\
\text { tietoinen digitaalisen } \\
\text { henkilöllisyyden hyö- } \\
\text { dyistä ja riskeistä. }\end{array}$ & $\begin{array}{l}\text { Osaan pitää yhteyttä } \\
\text { muihin käyttämäl- } \\
\text { lä useita viestintä- } \\
\text { kanavia ja niiden } \\
\text { kehittyneempiä } \\
\text { ominaisuuksia. Tun- } \\
\text { nen verkkoetiketin } \\
\text { periaatteet ja osaan } \\
\text { soveltaa niitä eri } \\
\text { tilanteissa. Tiedän, } \\
\text { miten osallistutaan } \\
\text { sosiaalisten verkkosi- } \\
\text { vustojen ja verkkoyh- } \\
\text { teisöjen toimintaan } \\
\text { ja miten niissä jul- } \\
\text { kaistaan sekä jaetaan } \\
\text { tietoja ja sisältöä. } \\
\text { Osaan käyttää aktiivi- } \\
\text { sesti joitakin verkko- } \\
\text { palvelujen perusomi- } \\
\text { naisuuksia. Osaan } \\
\text { luoda syötteitä ja } \\
\text { keskustella niistä yh- } \\
\text { dessä muiden kanssa } \\
\text { yksinkertaisien di- } \\
\text { gitaalisien kanavien } \\
\text { välityksellä. Osaan } \\
\text { muokata digitaalis- } \\
\text { ta henkilöllisyyttäni } \\
\text { sekä seurata digitaa- } \\
\text { lista jalanjälkeäni. }\end{array}$ & $\begin{array}{l}\text { Käytän monenlaisia viestin- } \\
\text { täkanavia. Osaaan soveltaa } \\
\text { verkkoetikettiä erilaisis- } \\
\text { sa digitaalisen viestinnän } \\
\text { tiloissa ja tilanteissa. Olen } \\
\text { kehittänyt strategioita } \\
\text { sopimattoman käytöksen } \\
\text { havaitsemiseksi. Osaan } \\
\text { käyttää tilanteeseen sopivia } \\
\text { digitaalisia viestintätapoja. } \\
\text { Osaan räätälöidä viestinnän } \\
\text { muotoa ja tapoja kohdeylei- } \\
\text { sön mukaan. Osaan käsitellä } \\
\text { minulle saapuvia erityyp- } \\
\text { pisiä viestejä. Osaaan jakaa } \\
\text { tietoja, sisältöä ja resursseja } \\
\text { aktiivisesti muiden kanssa } \\
\text { verkkoyhteisöissä, verkos- } \\
\text { toissa ja yhteiskäyttöalus- } \\
\text { toissa. Olen aktiivisesti } \\
\text { mukana erilaisissa verkkoti- } \\
\text { loissa. Tiedän, miten osallis- } \\
\text { tutaan aktiivisesti verkossa, } \\
\text { ja osaan käyttää monia eri- } \\
\text { laisia verkkopalveluja. Käy- } \\
\text { tän usein ja luontevasti digi- } \\
\text { taalisia yhteisöllisiä kanavia, } \\
\text { joilla voin tuottaa ja jakaa } \\
\text { tietoja sekä sisältöä. Osaan } \\
\text { käyttää useita digitaalisia } \\
\text { henkilöllisyyksiä tarkoituk- } \\
\text { sen mukaan, valvoa verk-- } \\
\text { koviestinnässä tuottamaani } \\
\text { tietoa sekä suojata digitaa- } \\
\text { lista mainettani. }\end{array}$ \\
\hline
\end{tabular}

Taulukossa 1 edistynyt taso C kuvaa parhaiten teknologiavälitteistä viestintäosaamista asiantuntijan toimintaympäristöissä. Vaikka teknologiavälitteinen viestintäosaaminen on jaettu osa-alueisiin, tulee huomioida, että selkeää rajanvetoa ei näiden välille voi tehdä, vaan ne integroituvat toisiinsa ja ovat osittain päällekkäiset ja etenkin itse viestintätilanteessa kaikkia voidaan soveltaa samanaikaisesti.

Asiantuntijan viestintäosaamista tarkasteltaessa on syytä huomioida Ferrarin (2013) lisäksi muitakin osaamiskuvauksia. Yksi mielenkiintoisimmista kuvauksista on Spitzbergin (2006) tietokonevälitteisen vuorovaikutusosaamisen malli (CMC Competence Model). Tietokonevälitteisen vuorovaikutusosaamisen malli pohjautuu Morrealen, Spitzbergin ja Bargen (2001) viestintäkompetenssimalliin. Tietokonevälitteisen vuorovaikutusosaamisen mallissa viestintäosaaminen nähdään motivaationa, tietona, 
taitona, kontekstina ja tuloksina. Spitzbergin (2006) mukaan viestintäosaaminen kehittyy viestintätilanteessa ja osaaminen vaihtelee kulttuuristen ja toiminnan kontekstien mukaan. (Spitzberg 2006.) Vuonna 2011 Spitzberg kehitti mallia lisäämällä siihen itsearvioinnin lisäksi vertaisarvioinnin, mikä mahdollisti sen, että yksilöt voivat arvioida toistensa viestintäosaamista. Mielenkiintoinen havainto uuden mallin testauksessa oli, että vertaisarvioinnit olivat parempia kuin itsearvioinnit. (Spitzberg 2011.) Waldeck ym. (2012) tutki liiketoiminnan alan osaamista ja näki teknologiavälitteiseen viestintäosaamiseen kuuluvan verkossa toimimisen pelisääntöjen soveltamisen sekä virtuaalisen verkottumisen. Tutkimuksessa tuotiin esiin myös yhteisöllisen median merkitys markkinoinnissa, myynnissä, oppimisessa, innovoinnissa ja verkostoitumisessa. Nämä teknologivälitteisen viestinnän osaamisalueet liittyvät aiemmin kuvattuihin asiantuntijoiden toimintaympäristöihin. Ferrarin (2013), Spitzbergin (2006) ja Waldeckin ym. (2012) lisäksi Lönnbladin ja Vartiaisen tutkimus (2012) osaamisalueista hajautetussa työssä on olennainen. Heidän mukaansa sekä työntekijöiden että johtajien tulee osata viestiä kirjallisesti ja suullisesti virtuaalisessa ympäristössä sähköisten työkalujen avulla. Kommunikaatiotaidot ja erilaisuuksien ymmärtäminen, kulttuuritekijät mukaan lukien, nousevat tärkeimmiksi kaikille kuuluviksi osaamisalueiksi. Myös Huhta (2010), Rajander-Juusti (2013) ja Hanhinen (2010) ovat todenneet, että osaamisvaatimukset kulttuurienväliselle ymmärrykselle ja kielitaidolle ovat kasvaneet työelämässä.

Edellä esitetyt näkemykset työelämässä vaadittavasta viestintäosaamisesta ovat hyvin linjassa viestinnän muutoksien kanssa. Mielenkiintoista onkin tutkia, miten asiantuntijoiden teknologiavälitteinen viestintäosaaminen nähdään suomalaisissa organisaatioissa.

\section{Tutkimuksen toteutus}

\section{Tutkimuskysymykset ja tutkimusmenetelmät}

Tutkimuksen tavoitteena oli tarkastella asiantuntijan työssä tarvittavaa teknologiavälitteistä viestintäosaamista ja vastata seuraaviin tutkimuskysymyksiin:

- Mitä viestintäkanavia- ja palveluja asiantuntijat käyttävät viestintään?

- Mitkä teknologiavälitteisen viestinnän osaamisalueet nähdään tärkeiksi asiantuntijatehtävissä?

- Mitä asiantuntijoiden teknologivälitteistä viestintäosaamista on kehitettävä työelämässä?

Tutkimus oli pääosin kvantitatiivinen, ja siinä käytettiin sähköistä kyselylomaketta. Kysely koostui viidestä osasta. Ensimmäisessä osassa oli 18 teknologiavälitteisen viestintäosaamiskuvauksen (Ferrari 2013) sekä muiden tutkimusten pohjalta laadittua väittämää. ${ }^{2}$ Toisessa osassa toistettiin samat väittämät, mutta osaamisen tärkeyden sijaan arvioitiin oman työyhteisön asiantuntijoiden tämänhetkistä teknologiavälitteistä viestintäosaamista. Kolmannessa osassa oli monivalintakysymyksiä ja avoimia kysymyksiä, 
jotka liittyivät vastaajan viestinnässä käyttämään kieleen sekä viestintäteknologiaan. Neljäs osuus sisälsi väittämiä työelämän muista yleisistä osaamisalueista, kuten kulttuurien ymmärtämisestä ja verkostoitumisesta. Väittämissä sovellettiin Likertin 5-portaista asteikkoa ( 1 = ei lainkaan tärkeää / osaamista ei ole $-5=$ erittäin tärkeää / erinomainen osaaminen). Viides osio koostui taustakysymyksistä, joilla selvitettiin vastaajan ikä, sukupuoli, koulutustausta ja koulutusala. Vastaajilta kysyttiin myös roolia työyhteisössä ja edustamansa organisaation toimialaa ja kokoa.

\section{Aineiston keruu ja analyysi}

Kyselylomakkeen aineisto kerättiin sosiaalisen median sekä sähköpostin avulla. ${ }^{3}$ Kyselyn jakamisessa hyödynnettiin Turun ammattikorkeakoulun alumnien sekä tutkijan omaa verkostoitumisyhteisöä LinkedInissä. Tutkija julkaisi linkin myös omissa Facebook- ja Twitter-profiileissaan. Sähköpostin välityksellä kyselyä lähetettiin Turun ammattikorkeakoulun kielikoulutuskeskuksen yritysasiakkuuksien yhteyshenkilöille ( $N=97)$. Tällä tavoin pyrittiin saamaan tutkimukseen eri toimialojen asiantuntijoiden näkemyksiä. Sosiaalisen median käytön vuoksi vastausprosenttia ei voida määritellä. Vastauksia kyselyyn saatiin 98.

Aineiston analyysissä käytettiin SPSS-ohjelmaa määrällisen aineiston analyysiin ja NVivo-ohjelmaa laadullisen aineiston kvantifiointiin. Ensin tehtiin pääkomponenttianalyysi väittämille, jotka liittyivät teknologiavälitteisen viestintäosaamisen tärkeyteen asiantuntijatehtävissä. Väittämät latautuivat selkeästi kahteen pääkomponenttiin: viestintäosaamisen tärkeys ja eettisen toiminnan tärkeys. Nämä kaksi komponenttia selittivät 51,72 prosenttia väittämien varianssista. Myös väittämät, jotka liittyivät työyhteisöissä olemassa olevaan teknologiavälitteiseen viestintäosaamiseen, latautuivat kahteen komponenttiin, jotka olivat olemassa oleva viestintäosaaminen ja olemassa oleva eettisen toiminnan ymmärtäminen. Näiden selitysosuus väittämien varianssista oli 49,03 prosenttia. Pääkomponenttianalyysi vahvisti täten teoreettisen viitekehyksen mukaiset pääkategoriat, joihin 18 väittämää sijoittuivat.

Näin vahvistettiin summamuuttujat viestintäosaamisen tärkeys asiantuntijatehtävissä, eettisen toiminnan tärkeys asiantuntijatehtävissä, työyhteisössä olemassa oleva viestintäosaaminen ja työyhteisössä olemassa oleva eettinen osaaminen. Mittarin reliabiliteettia mitattiin Cronbachin Alpha -kertoimella, joka oli kaikissa muodostetuissa summamuuttujissa yli o,8. Voitiin siis tulkita, että niihin kuuluvat muuttujat olivat keskenään yhdenmukaisia. Analyysin myöhemmässä vaiheessa luotiin 2 uutta summamuuttujaa: viestintäosaamisen kuilu sekä eettisen osaamisen kuilu. Analyysissa käytettiin suureksi osaksi kuvailevaa lähestymistapaa sekä yksisuuntaista varianssianalyysiä (ANOVA) otoskoon ollessa lähes sata ja summamuuttujien jakaumien ollessa likimain normaalisti jakautuneita. ${ }^{4}$ Yksisuuntaisella varainssianalyysillä selvitettiin, onko vertailtavien ryhmien keskiarvojen välillä merkitseviä eroja. Kun aineisto ei ollut normaalisti jakautunut, käytettiin Kruskall-Wallisin testiä ryhmien välisiä eroja arvioitaessa. Tilanteissa, joissa vertailtavia ryhmiä oli kaksi, keskiarvoerojen merkitsevyyttä tutkittiin t-testiä käyttäen. Muuttujien välistä yhteyttä mitattiin korrelaatiolla. 
Kyselyyn vastasi 98 henkilöä, joista $52 \%$ oli naisia. Vastaajien keski-ikä oli 43 vuotta; heistä nuorin oli 22 -vuotias ja vanhin 66 -vuotias. Vastaajista $60,2 \%$ oli suorittanut korkeakoulututkinnon ja $23,5 \%$ ammattikorkeakoulututkinnon. Asiantuntija-asemassa toimi $58,2 \%$ ja esimies- ja johtaja-asemassa työskenteli $24,5 \%$ vastaajista. Vastaajien taustaorganisaatiot toimivat pääosin koulutusalalla $(31,6 \%)$ ja teollisuudessa $(16,3$ \%). Toimialoista kuljetus, varastointi ja tietoliikenne (7,14 \%) sekä sähkö-, kaasu- ja vesihuolto $(6,12 \%)$ olivat seuraavaksi vahvimmin edustettuina. Yksittäisiä vastaajia oli myös rahoitusalalta, rakennusalalta, julkisen hallinnon, maatalouden, terveydenhuolIon ja sosiaalipalvelujen sekä tukku- ja vähittäiskaupan aloilta. Suurin osa vastaajista (57,1 \%) työskenteli suuryrityksissä eli yrityksissä, joissa on vähintään 250 työntekijää. Mikroyrityksiä, joissa työskentelee alle 10 henkilöä, edusti 10,2 \% vastaajista.

\section{Tutkimustulokset}

\section{Viestintäkanavat ja -palvelut sekä viestintäkieli asiantuntijayhteisöissä}

Vastaajia pyydettiin kertomaan, mitkä ovat viisi eniten käytettyä viestintäkanavaa ja -palvelua heidän omassa työssään. Jotta voitaisiin vertailla työyhteisöissä käytettäviä viestintäkanavia ja -teknologioita nyt ja tulevaisuudessa, vastaukset jaettiin viestintäpalvelutyyppeihin ja niiden yhteen lasketut mainintakerrat esitetään kuviossa 1.

Kuvio 1. Vastaajien käyttämät viestintäpalvelut tällä hetkellä ja näkemykset siitä, minkä viestintäpalvelujen käytön uskotaan tulevaisuudessa kasvavan (mainintojen määrä)

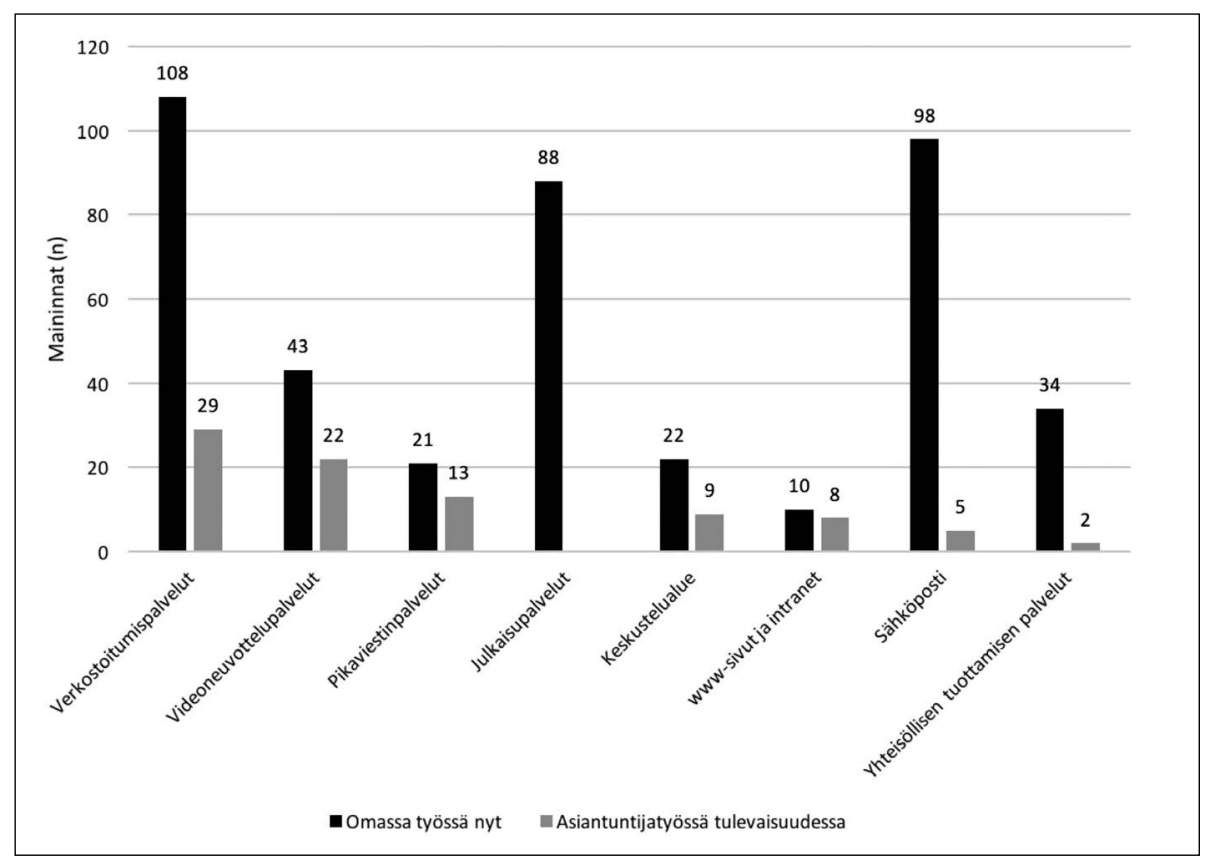


Vastaajista 98 ilmoitti käyttävänsä sähköpostia viestintään ja heistä 87 käyttää sitä pääasiallisena viestintäkanavana. Tämä tarkoittaa, että 11 vastaajaa käytti pääsääntöisesti jotain muuta kuin sähköpostia viestiessään työtehtävissään.

Toiseksi eniten yksittäisiä käyttäjiä oli LinkedInillä $(n=57)$ ja kolmanneksi Facebookilla $(n=51)$. Nämä on taulukossa luokiteltu verkostoitumispalvelujen alle. Myös erilaisten julkaisupalvelujen, kuten blogien $(n=42)$ ja Youtuben $(n=41)$ käyttö oli suosittua työtehtävissä.

Vastaajilta pyydettiin myös arviota siitä, minkä viestintäkanavan tai -palvelun käytön he uskovat tulevaisuudessa lisääntyvän asiantuntijatehtävissä. Eniten uskottiin erilaisten verkostoitumispalvelujen lisääntymiseen. Mainittuja palveluja ovat Facebook $(n=9)$, LinkedIn (12) sekä Yammer $(n=8)$. Toiseksi eniten mainintoja saivat videoneuvottelupalvelut, kuten Lync, Skype ja Adobe Connect. Myös pikaviestimien ja erityisesti Twitterin ( $n=8)$ käytön arvioitiin lisääntyvän. Muutamat vastaajista uskoivat myös sähköpostin käytön lisääntymiseen $(n=5)$. Näistä verkostoitumispalvelut ja sähköposti katsotaan eriaikaisiksi palveluiksi ja videoneuvottelupalvelut sekä pikaviestimet samanaikaisiksi. Kaikki voidaan tulkita monimediaisiksi ja sähköposti vähiten vihjeitä, kuten ilmeitä ja eleitä välittäväksi.

Suurin osa vastaajista ( $n=95)$ kertoi viestivänsä työtehtävissään teknologian välityksellä suomen kielellä. Vastaajista 83 ilmoitti käyttävänsä myös englantia, 33 ruotsia, 10 saksaa ja 1 venäjää. Näiden lisäksi mainittiin käytettävän ranskaa $(n=2)$, italiaa $(n=2)$, japania $(n=1)$ ja unkaria $(n=1)$. Sitä, kuinka usein tai kuinka paljon kieliä työssä käytettiin, ei selvitetty, eikä myöskään sitä, millä kielellä viestittäessä käytettiin mitäkin viestintäpalvelua.

\section{Viestintäosaamisen ja eettisen osaamisen tärkeys asiantuntijatehtävissä}

Seuraavaksi tutkimuksella haluttiin selvittää, mitä teknologiavälitteisen viestinnän osaamisalueita pidetään tärkeinä asiantuntijatehtävissä yksittäisten muuttujien tasolla. 
Taulukko 2. Teknologiavälitteisen viestintäosaamisen tärkeys asiantuntijatehtävissä ( $N=98)$

\begin{tabular}{|c|c|c|}
\hline Viestintäosaamisen tärkeys asiantuntijatehtävissä & ka & kh \\
\hline Osaa jakaa tietoa viestintäteknologian avulla & 4,58 & ,59 \\
\hline Osaa olla vuorovaikutuksessa kirjallisesti teknologian välityksellä & 4,47 & ,68 \\
\hline Osaa neuvotella virtuaalisesti hyödyntäen näytön ja tiedostojen jakamista & 4,29 & ,85 \\
\hline Osaa olla vuorovaikutuksessa suullisesti teknologian välityksellä & 4,24 & ,79 \\
\hline Osaa olla vuorovaikutuksessa virtuaalisesti muulla kuin suomen kielellä & 4,2 & ,84 \\
\hline $\begin{array}{l}\text { Osaa hyödyntää viestintäteknologiaa/-palveluja oman osaamisen } \\
\text { kehittämiseksi (esim. lukea ammattikirjallisuutta sähköisessä muodossa) }\end{array}$ & 4,09 & ,86 \\
\hline Osaa toimia yhteisöllisesti virtuaalisissa verkostoissa & 4,06 & ,91 \\
\hline $\begin{array}{l}\text { Osaa valita oikeat viestintäkanavat kommunikaatioon (esim. chat } \\
\text { pikakeskusteluun, wiki raportin tuottamisen) }\end{array}$ & 4,01 & ,88 \\
\hline $\begin{array}{l}\text { Ymmärtää kulttuuritekijöiden vaikutuksen teknologian välityksellä } \\
\text { viestittäessä }\end{array}$ & 3,92 & ,92 \\
\hline Osaa suunnitella tiedonhankintaprosessia & 3,9 & , 81 \\
\hline Osaa käyttää verkossa olevia itselle tärkeitä palveluja esim. lakineuvontaa & 3,8 & ,85 \\
\hline \multicolumn{3}{|l|}{ Eettisen toiminnan tärkeys asiantuntijaviestinnässä } \\
\hline Tunnistaa verkossa viestimisen riskit & 4,73 &, 51 \\
\hline Osaa hallita käyttäjätunnuksiaan & 4,56 & ,63 \\
\hline Noudattaa organisaation verkossa toimimisen pelisääntöjä & 4,52 & ,65 \\
\hline Osaa toimia eettisesti verkossa viestittäessä & 4,46 & ,69 \\
\hline Tuntee lähdekritiikin ja tekijänoikeuksien perusteet & 4,32 & , 87 \\
\hline $\begin{array}{l}\text { Osaa erottaa ammattiprofiilin ja vapaa-ajan profiilin esim. } \\
\text { verkostoitumispalveluissa }\end{array}$ & 4,3 & 0,9 \\
\hline Osaa erottaa vapaa-ajan ja työajan viestintäteknologian käytön & 4,06 & ,94 \\
\hline
\end{tabular}

Kaikki esitetyt osaamisalueet nähtiin tärkeinä, mutta eettisen toiminnan pääkategorian tärkeys korostui vastauksissa. Tärkeimmäksi arvioitiin verkossa viestimisen riskien tunnistaminen. Myös osaaminen, joka liittyi käyttäjätunnusten hallintaan sekä organisaation netissä toimimisen pelisääntöjen noudattamiseen, arvioitiin tärkeiksi osaamisalueeksi.

Viestintäosaamisen pääkategoriassa tiedon jakamisen osaaminen sekä kirjallisen vuorovaikutuksen osaaminen arvioitiin tärkeimmiksi. Tärkeäksi koettiin myös se, että asiantuntijat osaavat neuvotella virtuaalisesti sekä hallitsevat suullisen vuorovaikutuksen teknologian välityksellä. 


\section{Työyhteisössä olevan viestintäosaamisen ja tarvittavan osaamisen kuilu}

Seuraavaksi tutkittiin, onko vastaajien työyhteisöissä niitä taitoja, jotka nähdään tärkeinä asiantuntijatehtävissä. Tämä tehtiin tarkastelemalla eroja muuttujien "tärkeys" ja "olemassa oleva osaaminen" välillä. Kaikki muuttujat otettiin mukaan tarkasteluun. Tarkastelua varten väittämät koodattiin uudelleen siten, että ei lainkaan tärkeää / osaamista ei ole sai arvon -2, ei kovin tärkeää / vähäinen osaaminen arvon -1, melko tärkeää / perusosaaminen arvon o, tärkeää / hyvä osaaminen arvon 1, erittäin tärkeää / erinomainen osaaminen arvon 2. Näiden avulla laskettiin erotusmuuttujat ilmentämään mahdollisia eroja.

Taulukko 3. Teknologiavälitteisen viestintäosaamisen kuilu asiantuntijatehtävissä ( $N=98)$.

\begin{tabular}{|c|c|c|}
\hline Viestintäosaamisen kuilu & $\begin{array}{l}\text { kuilun } \\
\text { ka }\end{array}$ & $\begin{array}{l}\text { kuilun } \\
\text { kh }\end{array}$ \\
\hline Osaa toimia yhteisöllisesti virtuaalisissa verkostoissa & $-1,13$ & 1,19 \\
\hline Osaa neuvotella virtuaalisesti hyödyntäen näytön ja tiedostojen jakamista & $-1,08$ & 1,28 \\
\hline $\begin{array}{l}\text { Ymmärtää kulttuuritekijöiden vaikutuksen teknologian välityksellä } \\
\text { viestittäessä }\end{array}$ & $-1,06$ & 1,21 \\
\hline Osaa jakaa tietoa viestintäteknologian avulla & -1 & 0,93 \\
\hline Osaa olla vuorovaikutuksessa virtuaalisesti muulla kuin suomen kielellä & $-0,95$ & 1,25 \\
\hline Osaa olla vuorovaikutuksessa suullisesti teknologian välityksellä & $-0,94$ & 1,08 \\
\hline $\begin{array}{l}\text { Osaa valita oikeita viestintäkanavia kommunikaatioon (esim. chat } \\
\text { pikakeskusteluun, wiki raportin tuottamisen) }\end{array}$ & $-0,94$ & 1,17 \\
\hline Osaa suunnitella tiedonhankintaprosessia & $-0,83$ & 0,95 \\
\hline Osaa olla vuorovaikutuksessa kirjallisesti teknologian välityksellä & $-0,77$ & 0,93 \\
\hline Osaa käyttää verkossa olevia itselle tärkeitä palveluja esim. lakineuvontaa & $-0,57$ & 1,01 \\
\hline $\begin{array}{l}\text { Osaa hyödyntää viestintäteknologiaa/-palveluja oman osaamisen } \\
\text { kehittämiseksi (esim. lukea ammattikirjallisuutta sähköisessä muodossa) }\end{array}$ & $-0,48$ & 1,15 \\
\hline \multicolumn{3}{|l|}{ Eettisen toiminnan kuilu } \\
\hline Tunnistaa verkossa viestimisen riskit & $-1,33$ & 0,93 \\
\hline Tuntee lähdekritiikin ja tekijänoikeuksien perusteet & $-1,01$ & 0,98 \\
\hline Osaa hallita käyttäjätunnuksiaan & -1 & 0,98 \\
\hline Noudattaa organisaation verkossa toimimisen pelisääntöjä & $-0,95$ & 1 \\
\hline $\begin{array}{l}\text { Osaa erottaa ammattiprofiilin ja vapaa-ajan profiilin esim. } \\
\text { verkostoitumispalveluissa }\end{array}$ & $-0,9$ & 1,21 \\
\hline Osaa toimia eettisesti verkossa viestittäessä & $-0,88$ & 1,09 \\
\hline Osaa erottaa vapaa-ajan ja työajan viestintäteknologian käytön & $-0,70$ & 1,15 \\
\hline
\end{tabular}


Taulukossa 3 ilmeneviä kuiluja tulkitaan seuraavasti: o= osaaminen vastaa tärkeyttä, -1 = osaaminen hieman jäljessä, -2 = osaaminen jäljessä, $-3=$ osaaminen paljon jäljessä, -4 = osaaminen täysin riittämätön.

Taulukossa on nähtävissä, että kaikilla viestintäosaamisen ja eettisen osaamisen pääkategorioiden osa-alueilla oli kuilu olemassa olevan osaamisen ja vaatimusten välillä. Suurin osaamiskuilu on arvioitu olevan verkossa viestimisen riskien tunnistamisessa $(k a=-1,33, k h=0,93)$. Kaikki 18 osaamiskuilua ovat tulkittavissa niin, että osaaminen on hieman jäljessä odotetusta. Kaikki erotusmuuttujat otettiin mukaan, kun niistä luotiin edelleen jatkoanalyyseja varten summamuuttujat viestintäosaamisen kuilu ja eettisen osaamisen kuilu.

\section{Sukupuolen merkitys teknologiavälitteisen viestintäosaamisen arvioinnissa}

Seuraavaksi tutkittiin, onko taustamuuttujien muodostamien ryhmien keskiarvojen välillä tilastollisesti merkitseviä eroja summamuuttujien arvioinneissa. Tuloksien mukaan tilastollisesti erittäin merkitsevät keskiarvojen erot liittyvät sukupuolten arvioihin eettisen osaamisen tärkeydestä $t(96)=5,07, p<0,001 ; 95 \% \mathrm{Cl}[0,29,0,66] \mathrm{ja}$ eettisen osaamisen kuilusta $t(96)=-3,31, p=0,001 ; 95 \% \mathrm{Cl}[-0,78,-0,20]$. Näiden tilastollisesti merkitsevien erojen suuruus on keskisuurta (Cohenin $d>0,50){ }^{5}$

Kuviossa 2 esitetään tilastollisesti merkitsevät tulokset miesten ja naisten näkemyksistä.

Kuvio 2 Naisten ja miesten näkemykset eettisen toiminnan tärkeydestä ja eettisen osaamisen kuilusta (ka)

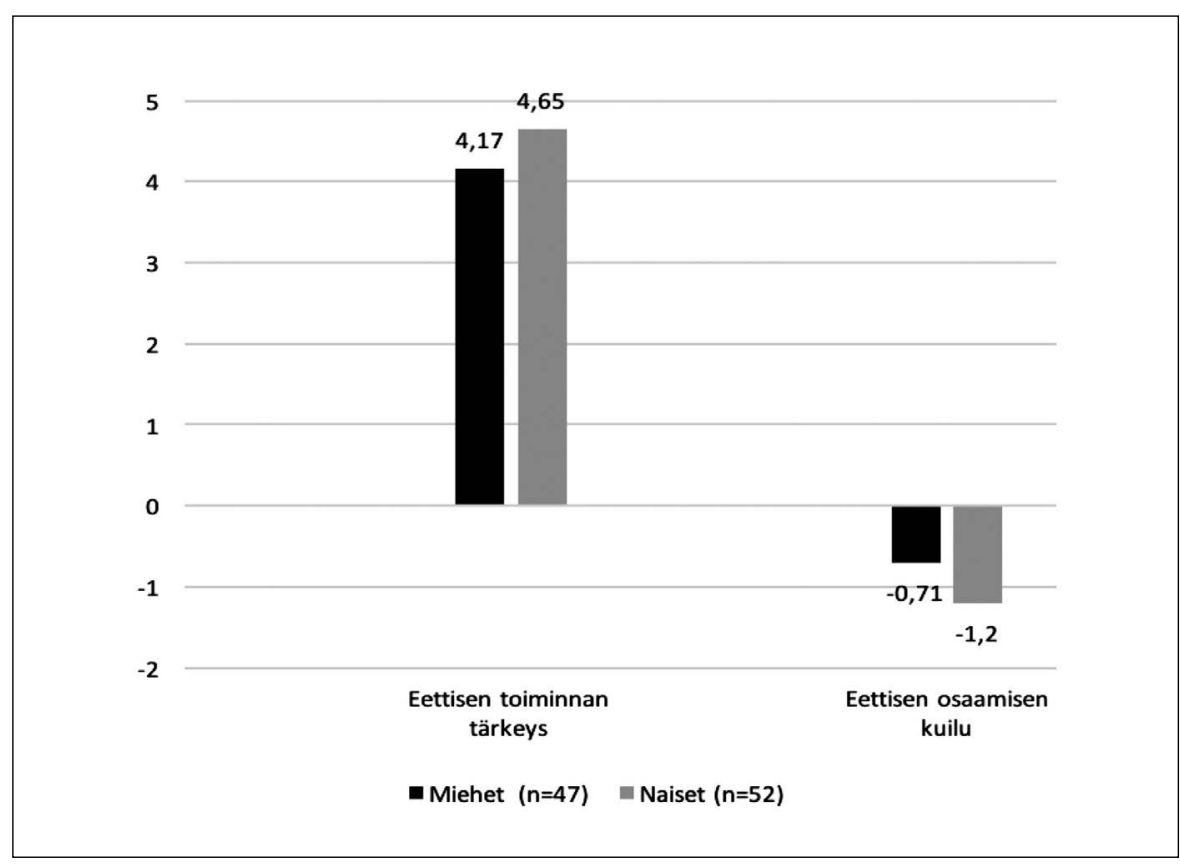


Kuvion 2 mukaan on tulkittavissa, että naiset kokivat eettisen osaamisen tärkeämpänä kuin miehet (naiset $k a=4,65, k h=0,35$; miehet $k a=4,17, k h=0,56$ ). Naiset arvioivat myös eettisen osaamisen kuilun miehiä suuremmaksi (naiset $k a=-1,20, k h=0,69$; miehet $k a=-0,71, k h=0,78)$. On kuitenkin huomattava, että eettisen osaamisen tärkeyden ja kuilun osalta miesten arvioiden hajonta on suurempi kuin naisten.

Tiivistäen voidaan todeta, että naiset arvioivat teknologivälitteisen viestintäosaamisen kauttaaltaan tärkeämmäksi kuin miehet. Samalla he kokivat osaamiskuilun suuremmaksi kuin miehet. Miesten ja naisten väliset näkemyserot korostuivat erityisesti eettisen toiminnan arvioinneissa.

\section{Teknologiavälitteinen viestintäosaaminen ja muut asiantuntijaosaamiset}

Tutkimuksessa tehtiin vertailu siitä, miten tärkeäksi viestintä teknologian välityksellä ja toisaalta viestintä kasvokkain koetaan asiantuntijatyössä. Kasvokkaisviestintä nähtiin erittäin tärkeänä $(k a=4,82, k h=0,42,95 \% \mathrm{Cl}[4,72 ; 4,89])$, mutta myös viestintä teknologian välityksellä koettiin tärkeäksi $(k a=4,15, k h=0,69,95 \% \mathrm{Cl}[4,01 ; 4,29])$.

Seuraavaksi tarkasteltiin kahden tämän tutkimuksen kannalta merkityksellisen asiantuntijaosaamisen, kulttuurien ymmärtämisen ja verkostoitumisen tärkeyttä. Molemmat osaamiset esitettiin kyselyssä yksittäisinä väittäminä. Verkostoituminen ( $k a$ 4,2 ja kh 0,77; $95 \% \mathrm{Cl}[4,05 ; 4,36]$ ) koettiin tärkeäksi, kun taas kulttuurien ymmärtäminen ( $k a$ 3,8 kh o,89; $95 \% \mathrm{Cl}[3,62 ; 3,97])$ nähtiin hieman vähemmän tärkeäksi asiantuntijan osaamisalueeksi. Keskiarvojen ja keskihajonnan lisäksi haluttiin selvittää, onko kulttuurien ymmärtämistä ja verkostoitumista eri lailla tärkeinä pitävien välillä eroja sen suhteen, miten he arvioivat summamuuttujien tärkeyttä.

Kruskall-Wallisin testin mukaan kulttuurien ymmärtämisen tärkeyttä eri lailla arvioivien välillä oli eroa viestintäosaamisen tärkeyden $\left(X^{2}(3)=23,92, p<0,001\right)$, eettisen toiminnan tärkeyden $\left(X^{2}(3)=18,51, p<0,001\right)$, viestintäosaamisen kuilun $\left(X^{2}(3)=18,65\right.$, $p<0,001)$ ja eettisen osaamisen kuilun $\left(X^{2}(3)=10,51, p=0,015\right)$ arvioissa. Näistä kolme ensimmäistä havaintoa ovat tilastollisesti erittäin merkitseviä.

Taulukossa 4 on esitetty tarkemmin, miten kulttuurien ymmärtämistä eri lailla tärkeinä pitävät arvioivat summamuuttujien tärkeyttä.

Taulukko 4. Kulttuurien ymmärtämistä eri lailla tärkeinä pitävien arviot summamuuttujista (ka)

\begin{tabular}{|c|c|c|c|c|c|}
\hline \multirow[b]{2}{*}{$\begin{array}{l}\text { Teknologiavälitteinen } \\
\text { viestintäosaaminen }\end{array}$} & \multicolumn{5}{|c|}{ Kulttuurien ymmärtäminen } \\
\hline & $\begin{array}{l}\text { ei kovin } \\
\text { tärkeää } \\
(n=5)\end{array}$ & $\begin{array}{l}\text { melko } \\
\text { tärkeää } \\
(n=35)\end{array}$ & $\begin{array}{l}\text { tärkeää } \\
(n=33)\end{array}$ & $\begin{array}{l}\text { erittäin } \\
\text { tärkeää } \\
(n=24)\end{array}$ & $\mathbf{p}$ \\
\hline Viestintäosaamisen tärkeys & 3,27 & 3,97 & 4,15 & 4,54 & $<0,001$ \\
\hline Eettisen toiminnan tärkeys & 3,74 & 4,25 & 4,52 & 4,67 & $<0,001$ \\
\hline Viestintäosaamisen kuilu & $-0,58$ & $-0,76$ & $-0,7$ & $-1,54$ & $<0,001$ \\
\hline Eettisen osaamisen kuilu & $-0,77$ & $-0,77$ & $-0,91$ & $-1,34$ & 0,015 \\
\hline
\end{tabular}


Keskiarvojen mukaan voidaan todeta, että "erittäin tärkeää" -ryhmä arvioi viestintäosaamisen ja eettisen toiminnan osaamisen tärkeämmäksi ja molemmat osaamiskuilut suuremmiksi kuin muut ryhmät.

Verkostoitumisosaamisen tärkeyden arviot jakautuivat ryhmiin "melko tärkeää", "tärkeää" ja "erittäin tärkeää". Kruskall-Wallisin testin mukaan tilastollisesti erittäin merkitsevät ryhmien väliset erot liittyivät viestintäosaamisen tärkeyteen $X^{2}(2)=27,29$, $p<0,001$ sekä viestintäosaamisen kuiluun $X^{2}(2)=15,20, p=0,001$. Merkitsevä ero havaittiin eettisen toiminnan tärkeydessä $X^{2}(3)=12,67, p=0,002$, ja melkein merkitsevä ero liittyi eettisen osaamisen kuiluun $X^{2}(2)=8,94, p=0,011$.

Taulukossa 5 on esitetty tarkemmin, miten verkostoitumista eri lailla tärkeinä pitävät arvioivat summamuuttujien tärkeyttä.

Taulukko 5. Verkostoitumista eri lailla tärkeinä pitävien arviot summamuuttujista (ka)

\begin{tabular}{|l|l|l|l|l|}
\hline \multirow{2}{*}{$\begin{array}{l}\text { Teknologiavälitteinen } \\
\text { viestintäosaaminen }\end{array}$} & $\begin{array}{l}\text { Verkostoituminen } \\
\text { tärkeää } \\
(\mathbf{n = 2 0 )}\end{array}$ & $\begin{array}{l}\text { tärkeää } \\
(\mathbf{n = 3 8 )}\end{array}$ & $\begin{array}{l}\text { erittäin } \\
\text { tärkeää } \\
(\mathbf{n = 4 0 )}\end{array}$ & $\mathbf{p}$ \\
\hline Viestintäosaamisen tärkeys & 3,71 & 4,05 & 4,45 & $<0,001$ \\
\hline Eettisen toiminnan tärkeys & 4,10 & 4,45 & 4,57 & 0,002 \\
\hline Viestintäosaamisen kuilu & $-0,34$ & $-0,93$ & $-1,21$ & 0,001 \\
\hline Eettisen osaamisen kuilu & $-0,53$ & $-1,03$ & $-1,10$ & 0,011 \\
\hline
\end{tabular}

Keskiarvot ovat tulkittavissa siten, että "erittäin tärkeää" -ryhmä arvioi viestintäosaamisen ja eettisen toiminnan osaamisen tärkeämpänä ja viestintäosaamisen kuilun suurempana kuin muut ryhmät. Eettisen osaamisen kuilu näyttäytyi suurimpana ryhmälle, joka arvioi verkostoitumisosaamisen tärkeänä.

Ryhmien välisien erojen lisäksi tarkasteltiin, onko kulttuurien ymmärtämisen ja verkostoitumisen tärkeydellä yhteys summamuuttujan arvioihin. Tämä tehtiin tarkastelemalla muuttujien korrelaatiota. Vastaajien arvio kulttuurien ymmärtämisestä korreloi viestintäosaamisen tärkeyden $\left(r_{s}=0,477, p<0,0005\right)$, eettisen osaamisen tärkeyden $\left(r_{s}=0,431, p<0,0005\right)$, viestintäosaamisen kuilun $\left(r_{s}=-0,340, p=0,001\right)$ ja eettisen osaamisen kuilun $\left(r_{s}=-0,297, p=0,003\right)$ kanssa. Myös verkostoitumisosaamisen tärkeydellä on yhteys viestintäosaamisen tärkeyteen $\left(r_{s}=0,529, p<0,0005\right)$, eettisen osaamisen tärkeyteen $\left(r_{s}=0,345, p<0,001\right)$, viestintäosaamisen kuiluun $\left(r_{s}=-0,378, p\right.$ $<0,0005)$ ja eettisen osaamisen kuiluun $\left(r_{s}=-0,257, p=0,011\right)$.

Tiivistetysti voidaan todeta, että vastaajat, jotka arvioivat kulttuurien ymmärtämisen ja verkostoitumisosaamisen merkittäviksi osaamisalueeksi asiantuntijatehtävissä, arvioivat myös teknologiavälitteisen viestintäosaamisen tärkeämmäksi ja osaamiskuilun suuremmaksi kuin ne vastaajat, jotka eivät koe kulttuurien ymmärtämistä ja verkostoitumisosaamista erityisen merkittävinä. 


\section{Pohdintaa}

Tämä artikkeli tarkasteli työelämän viestintää sekä asiantuntijoilta vaadittavaa teknologiavälitteistä viestintäosaamista. Ensinnäkin kasvokkaisviestintä koettiin yhä kaikkein tärkeimmäksi tavaksi viestiä. Kuitenkin teknologian välityksellä viestittäessä, ehkä hieman yllättävästikin, sähköposti oli selkeästi käytetyin työelämän viestintätilanteissa. Kasvokkaisviestinnän ollessa edelleen tärkein tapa viestiä olisi voinut olettaa, että videoneuvottelupalvelujen käytöllä korvattaisiin niitä tilanteita, joissa kasvokkain viestiminen ei ole mahdollista. Videoneuvottelut mahdollistavat viestimisen niin, että välitetään samanaikaisesti kuvaa, videota, tekstiä, ääntä ja erityisesti sosiaalisia vihjeitä eli ne voivat vastata monin tavoin kasvokkaista viestintätilannetta (Tidwell \& Walther 2002; Dennis ym. 2008). Toisaalta, kuten tässä artikkelissa on jo aiemmin tuotu esiin, monet tutkimukset ja teoriat, jotka tarkastelevat viestintäkanavien mahdollistamia vihjeitä, ovat esittäneet sekä niiden vähyydelle että runsaudelle viestintää tukevia väitteitä. Viestintäkanavan valintaan vaikuttavat sekä viestintätilanne että yksilön omat näkemykset teknologiavälitteisestä viestinnästä. (vrt. Daft \& Lengel 1984; Tidwell \& Walther 2002; Dennis ym. 2008; Twine \& Brown 2011.)

Videoneuvottelujen melko alhaiseen käyttöön voivat edellä mainittujen lisäksi vaikuttaa vastaajien kokemukset teknologian toimivuudesta (Spitzberg 2006; Kimbrough ym. 2013;Treem ym. 2015) tai epävarmuus omasta osaamisesta. Alhainen käyttö voi selittyä yksinkertaisesti myös siitä syystä, että oma organisaatio ei tarjoa mahdollisuutta videoneuvotteluihin. Kuitenkin vastaajien usko siihen, että niin videoneuvottelupalvelujen kuin verkostoitumispalvelujen käyttö asiantuntijatehtävissä lisääntyy, oli melko vahva. Tämä näkemys tulevaisuudesta tukee käsitystä, jossa viestintä muuttuu alati vuorovaikutteisemmaksi mahdollistaen asiantuntevan ja monimutkaisistakin asioista viestinnän monikulttuurisissa verkostoissa (Lönnblad \& Vartiainen 2012; Ladegaard \& Jenks 2015). Toimintaympäristöjen kansainvälisyyttä kuvasi se, että lähes kaikki vastaajat käyttivät suomen lisäksi englantia työtehtävissään teknologian avulla viestittäessä. Jatkossa tulisikin tutkia, mitä viestintäpalvelua ja -kanavia käytetään eri kielillä viestittäessä ja onko kulttuurilla merkitystä siihen, minkä tyyppisiä viestintäkanavia suositaan esimerkiksi sellaisessa viestintätilanteessa, jossa vastausta odotetaan nopeasti.

Teknologiavälitteisessä asiantuntijan viestintäosaamisessa korostui selkeästi eettinen toiminta. Asiantuntijoiden tulee näin tunnistaa oman toiminnan mahdolliset negatiiviset vaikutukset itseensä, sidosryhmiin ja omaan organisaatioon. Näitä ovat esimerkiksi yksilön väsyminen työnteon rajojen hämärtyessä, asiakastietojen vuotaminen ja työnantajayrityksen maineen pilaaminen (esim. Mazmanian ym. 2013; Ojala \& Pyöriä 2013; Mark ym. 2014; Kushlev \& Dunn 2015). Tämän artikkelin taustalla olevissa tutkimuksissa riskien tunnistamista ei ole korostettu eikä tuotu esiin laajasti. Spitzberg ja Cupach $(2002,583)$ sekä Valkonen (2003, 26-39) viittaavat tarkoituksenmukaiseen ja hyväksyttävään toimintaan. Ferrari (2013) ja Waldeck ym. (2012) tuovat esiin, että verkossa viestittäessä tulee noudattaa verkkoetikettiä. Koska tulosten mukaan riskien tunnistaminen oli tärkein verkossa viestimisen osaamisalue, tulee tähän kiinnittää enemmän huomiota organisaatioissa. Mahdollisten riskien ymmärtäminen kaikkien osapuol- 
ten kannalta on tärkeää myös siksi, että asiantuntijan ollessa epävarma siitä, miten hänen tulisi toimia, saattaa hänen halukkuuteensa viestiä teknologian avulla alentua. Verkossa viestimisen riskien tunnistamista voidaan pitää verkossa viestimisen perusedellytyksenä. Eettinen näkökulma ja riskien ymmärtäminen korostuivat erityisesti naisten vastauksissa. Tähän saattaa vaikuttaa se, että naiset viestivät miehiä enemmän sosiaalisissa verkostoissa ja verkostoituvat enemmän kuin miehet (Kimbrough ym. 2013). Henkilökohtaiset kokemukset sosiaalisissa verkostoissa toimimisesta voivat korostaa etenkin eettisen toiminnan tärkeyttä (vrt. Treem ym. 2015). Tästä voi tehdä johtopäätöksen, jonka mukaan asiantuntijoiden kokemuksen lisääntyessä sosiaalisissa verkostoissa myös eettisen toiminnan ja riskien ymmärtämisen merkitys kasvaa.

Osaamisalueista tärkeiksi koettiin myös tiedon jakaminen ja vuorovaikutus kirjallisesti ja suullisesti sekä virtuaaliset neuvottelutaidot vieraalla kielellä. Spitzberg (2006), Waldeck ym. (2012), Lönnblad ja Vartiainen (2012), Ferrari (2013) ja Hansen (2015) ovat tuoneet vuorovaikutuksen esiin, mutta Lönnblad ja Vartiainen (2012) sekä Hansen (2015) huomioivat erityisesti myös sen, että teknologian välityksellä viestittäessä ei aina viestitä omalla äidinkielellä eikä saman kulttuurin edustajien kesken. Myös Spitzberg (2006) esittää, että kulttuurisilla konteksteilla on merkitystä teknologiavälitteiselle viestintäosaamiselle. Kielitaito ja kulttuurien ymmärtäminen ovat asiantuntijatehtävien keskeisiä osaamisia eikä niitä ei voi irrottaa teknologiavälitteisen viestintäosaamisen käsitteestä.

Kolmanneksi tutkimuksessa tarkasteltiin mahdollisia osaamiskuiluja. Mielenkiintoista on, että tulosten mukaan asiantuntijoiden osaaminen ei ollut vaaditulla tasolla yhdelläkään mainitulla teknologiavälitteisen viestintäosaamisen 18 osa-alueella. Erityisesti tulisi kehittää verkossa viestimisen riskien tunnistamiseen, virtuaalisissa verkostoissa toimimiseen, virtuaalisiin neuvottelutaitoihin ja kulttuuritekijöiden vaikutuksen ymmärtämiseen liittyvää osaamista. Kolme ensin mainittua osaamiskuilua olivat ennakoitavissa, mutta kulttuuritekijöiden vaikutuksen ymmärtämisen osaamiskuilu on yllättävä lähinnä siksi, että se ei sijoittunut kärkisijoille osaamisen tärkeyttä arvioidessa. Osaamiskuilu ei ole kuitenkaan miltään osin suuri. Tulos on kuitenkin huolestuttava, sillä asiantuntijan toimiessa kansainvälisissä verkostoissa juuri nämä voisi mieltää osaamisen perusedellytyksiksi. Tulokset antavatkin viitettä asiantuntijoiden osaamiskuilun kasvusta. Ne vastaajat, jotka arvioivat kulttuurien ymmärtämisen ja verkostoitumisen erittäin tärkeiksi asiantuntijan osaamisalueiksi arvioivat teknologiavälitteisen viestintäosaamisen sekä sen osaamiskuilun asiantuntijatehtävissä suurimmiksi. Tämä tulos tukee Lönnbladin ja Vartiaisen (2012) sekä Hansenin (2015) näkemystä, jonka mukaan erityisesti kulttuuristen erilaisuuksien ymmärtäminen hajautetussa globaalissa työssä on osa viestintäosaamista.

Kun arvioidaan tutkimuksen pääasiallisena taustakuvauksena toiminutta Ferrarin (2013) teknologiavälitteisen viestintäosaamisen itsearviointitaulukkoa, voidaan todeta, että se toimii hyvin myös asiantuntijalta vaadittavaa osaamista kuvattaessa. Osaamiskuvaukseen tulee kuitenkin tehdä joitakin lisäyksiä. Ferrarin (2013) osaamiskuvaus keskittyy vahvemmin yksilölähtöiseen tarkasteluun, mutta viestintäosaamista tulisi pohtia myös organisaatiolähtöisesti (ks. Waldeck ym. 2012). Tutkimustulosten 
mukaan tärkeintä on, että verkossa toimimisen riskien ymmärtäminen ja ylipäätään eettisen toiminnan osaaminen teknologian välityksellä viestittäessä huomioidaan vahvemmin. Toki monet riskien ymmärtämisen ja eettisen toiminnan näkökulmat ovat organisaatiokohtaisia ja samalla tilannesidonnaisia, eivätkä ne ole yleistettävissä. Siksi näitä ei välttämättä voidakaan yksityiskohtaisesti avata osaamiskuvauksissa. Niiden tärkeyttä tulisi kuitenkin korostaa muun muassa esimerkkien avulla. Tämän lisäksi kulttuurien ymmärtämisellä on eittämättä yhteys asiantuntijan viestintään, sillä se vaikuttaa muun muassa viestinnässä käytettävän teknologian valintaan. Ferrari (2013) sijoittaa kulttuurien ymmärtämisen verkkoetikettiosaamisen alle, mutta se tulisi nostaa selkeästi esiin. Kielitaitoakaan ei voi olla huomioimatta, kun tarkastellaan viestintäosaamista ja huomioidaan alati kansainvälistyvät toimintaympäristöt. Kielitaidosta on olemassa vastaavanlainen kolmen tason ( $A-C$ ) kuvaus (Common European Framework of Reference for Languages, CEFR) kuin minkä Ferrari (2013) on esittänyt teknologiavälitteisestä viestintäosaamisesta. Näiden osaamiskuvausten välillä tulisi jatkossa tehdä vertailua ja yhdistämistä. Näillä lisäyksillä, yhdistäen siihen Spitzbergin (2006); Waldeckin ym. (2012) ja Lönnbladin ja Vartiaisen (2012) näkemyksiä, teknologiavälitteisen viestintäosaamisen itsearviointitaulukkoa voidaan soveltaa entistä paremmin asiantuntijoiden ja asiantuntijayhteisöjen viestintäosaamisen kehittämisessä ja arvioinnissa sekä yksilöiden että organisaatioiden näkökulmasta.

Loppujen lopuksi kyse on neljästä asiantuntijan osaamisalueesta, joita ei voi eikä tulekaan erottaa toisistaan. Teknologiavälitteinen viestintäosaaminen, verkostoitumisosaaminen, kulttuurien ymmärtäminen ja kielitaito tulisi organisaatioissa huomioida kokonaisvaltaisesti osana asiantuntijuuden kehittämistä. Tärkeä lähtökohta osaamisen kehittämiselle on, että viestintäteknologia tulisi ymmärtää sosiaalisuuden ja verkostoitumisen mahdollistajaksi eikä pelkäksi välineeksi.

Tämän tutkimuksen tuloksia arvioitaessa tulee huomioida, että vastaajamäärä ei ollut kovin suuri ja suurin osa vastaajista edusti koulutusalaa. Kuitenkin aineistoa kertyi runsaasti vastaajaa kohden, mikä lisää tutkimuksen uskottavuutta (Hänninen 2016, 113). Toinen huomio liittyy siihen, että Ferrarin (2013) itsearviointitaulukkoa sovellettiin vastaajien työyhteisön osaamisen arviointiin. Tällainen vertaisarviointi saattaa antaa positiivisemman yleiskuvan osaamisen tasosta kuin vastaajien itsearviointi olisi tuottanut. Myös vastaajien näkemykset voivat poiketa suurestikin toisistaan. (ks. Spitzberg 2015). Analyysiä olisi voitu monipuolistaa ensinnäkin laadullisella otteella haastattelemalla asiantuntijaorganisaatioiden henkilöstön osaamisen kehittäjiä. Toiseksi olisi ollut mielenkiintoista selvittää, mitä viestintäkanavia tai -palveluja hyödynnetään milläkin kielellä viestittäessä. Kolmanneksi tulisi viestinnän tilannesidonnaisuus huomioida paremmin (Spitzberg \& Dillard 2002). Kuitenkin tällä tutkimuksella kyettiin tuomaan esiin selkeitä teknologiavälitteisen viestinnän osa-alueita, joiden merkitys on suuri asiantuntijoiden toimintaympäristöissä. Tuloksia voivat hyödyntää erityisesti henkilöstöjohtajat asiantuntijaorganisaatioiden osaamisen kehittämisen prosesseissa ja rekrytoinnissa. Tämän lisäksi tulokset tulisi huomioida korkeakoulutuksessa, jotta asiantuntijaorganisaatioilla on mahdollisuus rekrytoida osaavaa henkilöstöä. 


\section{Viitteet}

1 Yleisesti käytössä olevia käsitteitä, jotka viittaavat teknologian avulla tapahtuvaan vuorovaikutukseen ihmisten välillä ovat mm. teknologiatuettu viestintä (computer mediated communication, CMC; technology mediated communication, TMC) ja digitaalinen viestintä (digital communication).

2 Esimerkkejä väittämistä: "Miten tärkeää on, että asiantuntijat osaavat neuvotella virtuaalisesti hyödyntäen näytön ja tiedostojen jakamista?" sekä "Miten tärkeää on, että asiantuntijat noudattavat organisaation verkossa toimimisen pelisääntöjä?".

3 Jotta kyselyä olisi helppo lähettää myös sosiaalisen median kautta, kyselyn saatekirje julkaistiin Google Drivessa. Tähän saatekirjeeseen sisällytettiin linkki Webropol-ohjelmassa olevaan kyselyyn. Saatekirje kyselylinkkeineen pilotoitiin ja vastaajilta pyydettiin vastaamisen lisäksi kommentteja saatteen ja kyselyn toimivuudesta, pituudesta sekä ymmärrettävyydestä. Ymmärrettävyyteen liittyen kyselylomakkeissa yleensäkin on riskinä, että vastaajat tulkitsevat käytettyjä määritelmiä eri tavoin (Saaranen-Kauppinen \& Puusniekka 2006). Esimerkiksi vastaajien omat tulkinnat siitä, mitä asiantuntijatehtävät tai viestintäosaaminen tarkoittaa, voivat erota toisistaan. Pilotoinnin jälkeen saatetta ja kyselyä muokattiin mahdollisimman yksiselitteiseksi ja selkeäksi.

$4 \quad$ Keskeisen raja-arvolauseen mukaan eri otoksista saatavien otoskeskiarvojen jakauma lähenee normaalijakaumaa otoskoon kasvaessa riippumatta siitä, minkälainen jakauma muuttujalla on perusjoukossa. Käytännössä on havaittu, että otoskoosta 30 ylöspäin ollaan useimmissa tapauksissa jo riittävän lähellä normaalijakaumaa. (Taanila 2014.)

5 Efektikoko kertoo, kuinka suurta naisten ja miesten välinen ero on. Cohenin d -mittaa käytettiin, koska vertailtiin kahden ryhmän keskiarvoja. Mittaa tulkitaan niin, että efektikoko on pieni, jos Cohenin $\mathrm{d}<0,20$, keskisuuri Cohenin d:n ollessa noin 0,40-0,45 ja suuri Cohenin d:n ollessa > 0,80. (Metsämuuronen 2013).

\section{Kirjallisuus}

Alasoini, Tuomo; Järvensivu, Anu \& Mäkitalo, Jorma (2012). Suomen työelämä vuonna 203o: Miten ja miksi se on toisennäköinen kuin tällä hetkellä? Helsinki: Työ- ja elinkeinoministeriö. TEM -raportteja 14/2012.

Berry, Gregory R. (2011). Enhancing effectiveness on virtual teams: Understanding why traditional team skills are insufficient. Journal of Business Communication 48:2, 186-206.

Common European Framework of Reference for Languages: Learning, Teaching, Assessment (2002). Council of Europe. Saatavilla: http://www.coe.int/t/dg4/linguistic/Source/Framework_EN.pdf (luettu 30.4.2015).

Cummings, Jeffrey (2013). The impact of intra-organizational social networking sites on impression formation. Journal of Information Systems Applied Research 6:2, 40-50.

Daft, Richard \& Lengel, Robert (1986). Organizational information requirements, media richness and structural design. Management Science 32:5, 554-571.

Dennis, Alan R., Fuller, Robert M. \& Valacich, Joseph. S. (2008). Media, tasks, and communication processes: A theory of media synchronicity. MIS Quarterly, 32:3, 575 -600.

Ek, Stefan \& Niemelä, Raimo (2010). Onko internetistä tullut suomalaisten tärkein terveystiedon lähde? Deskriptiivistä tutkimustietoa vuosilta 2001 ja 2009. Informaatiotutkimus 29:4.

Ferrari, Anusca (2013). DIGCOMP: a Framework for Developing and Understanding Digital Competence in Europe. European Commission, Joint Research Centre, Institute for Prospective Technological Studies. (Report EUR 26035 EN).

Gruber, Hans; Lehtinen, Erno; Palonen, Tuire \& Degner, Stefan (2008). Persons in shadow: Assessing the social context of high abilities. Psychology Science Quarterly 50:2, 237-258.

Hakkarainen, Kai; Lallimo, Jiri \& Toikka, Seppo (2012). Kollektiivinen asiantuntijuus ja jaetut tietokäytännöt. Aikuiskasvatus 32:4, 246-256.

Hakkarainen, Kai; Lallimo, Jiri; Toikka, Seppo \& White, Hal (2011). Cultivating collective expertise within innovative knowledge-practice networks. Teoksessa Ludvigsen; Sten; Lund; Anders; Rasmussen, Ingvill \& Säljö, Roger (toim.), Learning Across Sites: New Tools, Infrastructures and Practices (69-86). Earli series: New Perspectives on Learning and Instruction. New York: Routledge.

Hanhinen, Taina (2010). Työelämäosaaminen: Kvalifikaatioiden luokitusjärjestelmän konstruointi. Tampereen yliopisto. Acta Universitatis Tamperensis; 1571. 
Hansen, Miriam, Fabriz, Sabine \& Stehle, Sebastian (2015). Cultural cues in students' computer-mediated communication: Influences on e-mail style, perception of the sender, and willingness to help. Journal of Computer-Mediated Communication 20:3, 278-294.

Hoy, Mariea Grubbs \& Milne, George (2010). Gender differences in privacy-related measures for young adult Facebook users. Journal of Interactive Advertising 10:2, 28-45.

Huhta, Marjatta (2010). Language and Communication for Professional Purposes. Needs Analysis Methods in Industry and Business and their Yield to Stakeholders. Helsinki: Helsinki University of Technology. Saatavilla: http://lib.tkk.fi /Diss/2010/isbn9789522482273/isbn9789522482273.pdf (luettu 15.1.2015).

Huhta, Marjatta (2013). Työelämän odotukset ja kieli- ja viestintätaidon arviointikohteet. Teoksessa AHOT korkeakouluissa. Kielet ja viestintä. TAMK, 8-21. Saatavilla: http://julkaisut.tamk.fi/PDF-tiedostot-web/ B/56-AHOTkorkeakouluissa.pdf (luettu 15.2.2014).

Hänninen, Vilma (2016). Aikuiskasvatuksen tutkimusmenetelmiä. Kuinka paljon on tarpeeksi? Aineiston määrä laadullisessa tutkimuksessa. Aikuiskasvatus 36:2, 109-113.

Julkunen, Raija (2008). Uuden työn paradoksit: Keskusteluja 200o-luvun työprosess(e)ista. Tampere: Vastapaino.

Jussila, Jari (2015). Social Media in Business-to-Business Companies' Innovation. Tampere: Tampereen teknillinen yliopisto.

Kimbrough, Amanda; Guadagno, Rosanna; Muscanell, Nicole \& Dill, Janeann (2013). Gender differences in mediated communication: Women connect more than do men. Computers in Human Behavior 29:3, 896-900.

Kleinbaum, Adam; Stuart, Toby \& Tushman, Michael (2008). Communication (and coordination?) in a Modern, Complex Organization. Boston, MA: Harvard Business School. Saatavilla: http://www.puyt.nl/ wp-content/uploads/2008/og/o9-004.pdf (luettu 15.1.2015).

Klitmøller, Anders \& Lauring, Jakob (2013). When global virtual teams share knowledge: Media richness, cultural difference and language commonality. Journal of World Business 48:3, 398-406.

Koskela, Lasse; Koskinen, Jari \& Lankinen, Pasi (2007). Viestintä verkostoissa ja innovaatioissa. WSOYpro.

Kostiainen, Emma (2003). Viestintä ammattiosaamisen ulottuvuutena. Jyväskylä Studies in Humanities 1. Jyväskylän yliopisto.

Kushlev, Kostadin \& Dunn, Elizabeth (2015). Checking email less frequently reduces stress. Computers in Human Behavior 43, 220-228.

KvantiMOTV (2015). Kvantitatiivisten menetelmien tietovaranto. Tampere: Yhteiskuntatieteellinen tietoarkisto. Saatavilla: http://www.fsd.uta.fi/menetelmaopetus/intro.html (luettu 12.6.2015).

Laajalahti, Anne (2014). Vuorovaikutusosaaminen ja sen kehittyminen tutkijoiden työssä. Jyväskylä: Jyväskylän yliopisto.

Ladegaard, Hans J. \& Jenks, Christopher J. (2015). Language and intercultural communication in the workplace: Critical approaches to theory and practice. Language and Intercultural Communication 15:1, $1-12$.

Lipnack, Jessica \& Stamps, Jefrey (2000). Virtual Teams: People Working Across Boundaries with Technology. New York: John Wiley \& Sons.

Lockwood, Jane (2015). Virtual team management: What is causing communication breakdown? Language and Intercultural Communication, 15:1, $125-140$.

Lönnblad, Johan \& Vartiainen, Matti (2012). Future Competences-Competences for New Ways of Working. Publication Series B, 12 University of Turku, Brahea Centre for Training and Development.

Majchrzak, Ann, Faraj, Samer, Kane, Gerald C. \& Azad, Bijan (2013). The contradictory influence of social media affordances on online communal knowledge sharing. Journal of Computer-Mediated Communication 19:1, 38-55.

Mark, Gloria; Wang, Yiran \& Niiya, Melissa (2014). Stress and multitasking in everyday college life: An empirical study of online activity. In: Proceedings of the SIGCHI Conference on Human Factors in Computing Systems. ACM 41-50.

Mazmanian; Melissa, Orlikowski, Wanda J. \& Yates, JoAnne (2013). The autonomy paradox: The implications of mobile email devices for knowledge professionals. Organization Science 24:5, 1337-1357.

Metsämuuronen, Jari (2013). Perusopetuksen matematiikan oppimistulosten pitkittäisarviointi vuosina 2005-2012. Helsinki: Opetushallitus.

Morreale, S. P., Spitzberg, B. H., \& Barge, J. K. (2001). Human Communication: Motivation, knowledge, Q skills. Belmont, CA: Wadsworth. 
Myers, Karen \& Sadaghiani, Kamyab (2010). Millennials in the workplace: A communication perspective on millennials' organizational relationships and performance. Journal of Business and Psychology $25: 2,225-238$.

Nonaka, Ikujiro \& Takeuchi, Hirotaka (2004). Hitotsubashi on Knowledge Management. Singapore: Wiley.

Ojala, Satu \& Pyöriä, Pasi (2013). Kotona työskentelyn yleisyys ja seuraukset: 64 Suomi eurooppalaisessa vertailussa. Työpoliittinen Aikakauskirja 1/2013.

Oostervink; Nick, Agterberg; Marlous, \& Huysman, Marleen (2016). Knowledge sharing on enterprise social media: Practices to cope with institutional complexity. Journal of Computer-Mediated Communication 21:2, 156-176.

Palonen, Tuire; Boshuizen, Henry P. \& Lehtinen, Erno (2014). How expertise is created in emerging professional fields. Promoting, Assessing, Recognizing and Certifying Lifelong Learning, 131-149. Dordrecht: Springer.

Rajander-Juusti, Ritva (2013). Liiketalouden osaamistarpeet - ennakointitietoa koulutuksen suunnittelun tueksi. Opetushallituksen julkaisuja. Raportit ja selvitykset 2013:1. Saatavilla: http://www.oph.fi/ download/146309_Liiketalousalan_osaamistarpeet.pdf (luettu 11.11.2013).

Rockinson-Szapkiw, Amanda J.; Baker, Jason D.; Neukrug, Edward \& Hanes, John (2010). The efficacy of computer mediated communication technologies to augment and support effective online helping profession education. Journal of Technology in Human Services 28: 3, 161-177.

Romiszowski, Alexander \& Mason, Robin (2004). Computer-mediated communication. Teoksessa Jonassen, David H. (toim.), Handbook of Research for Educational Communications and Technology, 397-431. Taylor \& Francis. Saatavilla: http://www.aect.org/edtech/ed1/15.pdf (luettu 10.1.2015).

Rubin, Anita (2012). FUTUREX-Future experts projektin Delfoi-tutkimus. Turun yliopiston koulutus-ja kehittämiskeskus Brahean julkaisuja B, 9.

Saaranen-Kauppinen, Anita \& Puusniekka, Anna (2006). KvaliMOTV - Menetelmäopetuksen tietovaranto. Tampere: Yhteiskuntatieteellinen tietoarkisto. Saatavilla http://www.fsd.uta.fi/menetelmaopetus/ kvali/index.html (luettu 12.11.2015).

Sivunen, Anu (2007). Vuorovaikutus, viestintäteknologia ja identifioituminen hajautetuissa tiimeissä. Jyväskylä Studies in Humanities 79. Jyväskylän yliopisto.

Smit, Edith; Van Noort; Guda \& Voorveld, Hilde A.M. (2014). Understanding online behavioural advertising: User knowledge, privacy concerns and online coping behaviour in Europe. Computers in Human Behavior 34,15-22.

Spitzberg, B. H. \& Cupach, W. R. (2002). Interpersonal skills. Teoksessa M. L. Knapp \& J. A. Daly (toim.) Handbook of Interpersonal Communication (3. painos). Thousand Oaks: Sage, 564-611.

Spitzberg, Brian H. (2006). Preliminary development of a model and measure of computer-mediated communication (CMC) competence. Journal of Computer-Mediated Communication 11:2, 629-666.

Spitzberg, Brian H. (2011). The interactive media package for assessment of communication and critical thinking (IMPACCT): Testing a programmatic online communication competence assessment system. Communication Education 60:2, 145-173.

Spitzberg, Brian H. (2015). Is past prologue, or just passed and lacking presence? International Journal of Intercultural Relations 48, 24-26.

Spitzberg, Brian. H. \& Dillard, James, P. (2002). Social skills and communication. Interpersonal Communication Research: Advances through Meta-Analysis, 89-107.

Stahl, Günter; Maznevski, Martha; Voigt, Andreas \& Jonsen, Karsten (2010). Unraveling the effects of cultural diversity in teams: A meta-analysis of research on multicultural work groups. Journal of International Business Studies 41:4, 690-709.

Taanila, Aki (2014). Tilastollisen päättelyn alkeet. Saatavilla: http://docplayer.fi/289565-Aki-taanilatilastollisen-paattelyn-alkeet.html (luettu 23.12.2015).

Tamminen, Sakari; Lehmuskallio, Asko \& Johnson, Mikael (2011). Yksityisyyden haasteet sosiaalisessa mediassa. Teoksessa Aaltonen-Ogbeide, Terhi; Saastamoinen, Pentti; Rainio, Heikki \& Vartiainen, Tero (toim.), Silmät auki sosiaaliseen mediaan. Eduskunnan tulevaisuusvaliokunnan julkaisu 4/2011.

Tidwell, Lisa. C. \& Walther, Joseph, B. (2002). Computer-mediated communication effects on disclosure, impressions, and interpersonal evaluations: Getting to know one another a bit at a time. Human Communication Research, 28:3, 317-348.

Tilastokeskus (2015). Palkansaajien lukumäärät ja kokonaistuntiansiot työnantajasektorin ja ammattiryhmän (Ammattiluokitus 2010) mukaan vuonna 2014. Saatavilla: http://www.stat.fi/til/ pra/2014/pra_2014_2015-10-14_tau_001_fi.html (luettu 23.10.2015). 
Treem, Jeffrey W., Dailey, Stephanie L., Pierce, Casey S. \& Leonardi, Paul M. (2015). Bringing technological frames to work: How previous experience with social media shapes the technology's meaning in an organization. Journal of Communication 65:2, 396-422.

Twine, Andrew \& Brown, Irwin (2011). Evaluating web conferencing tool effectiveness. Proceedings of the South African Institute of Computer Scientists and Information Technologists. Conference on Knowledge, Innovation and Leadership in a Diverse, Multidisciplinary Environment, 239-248.

Tynjälä, Päivi (2010). Asiantuntijuuden kehittämisen pedagogiikkaa. Teoksessa Collin, Kaija; (toim.), Luovuus, oppiminen ja asiantuntijuus. Helsinki: WSOYpro, 79-95.

Valkonen, Tarja (2003). Puheviestintätaitojen arviointi: Näkökulmia lukiolaisten esiintymis- ja ryhmätaitoihin. Jyväskylä: Jyväskylän yliopisto.

Varpelaide, Heidi (2013). Verkkoluentoja ja virtuaalitapaamisia - liiketalouden aikuiskoulutuksesta valmiuksia työelämän verkkoviestintään. Teoksessa Minkkinen, Eila (toim.), Meillä tehdään!: SAMKista apua yritysten toiminnan kehittämiseen. Satakunnan ammattikorkeakoulu, sarja D, muut julkaisut 6/2013, 36-39.

Veltsos, Jennifer R. \& Veltsos, Christophe (2010). Teaching responsibly with technology-mediated communication. Business Communication Quarterly 73:4, 463-467.

Waldeck, Jennifer; Durante, Cathryn; Helmuth, Briana \& Marcia, Brandon (2012). Communication in a changing world: Contemporary perspectives on business communication competence. Journal of Education for Business 87:4, 230-240.

Walther, Joseph. B. (1996). Computer-mediated communication impersonal, interpersonal, and hyperpersonal interaction. Communication Research 23:1, 3-43.

Walther, Joseph. B (2012). Interaction through technological lenses: Computer-mediated communication and language. Journal of Language and Social Psychology 31, 397-414

Walther, J. B. (2016). Overattribution of liking in computer-mediated communication. Communication Research 43:3, 372-390.

Waters, Richard \& Lemanski, Jennifer (2011). Revisiting strategic communication's past to understand the present: Examining the direction and nature of communication on Fortune 500 and Philanthropy 400 web sites. Corporate Communications: An International Journal 16: 2, 150-169.

Williams, David; Crittenden, Victoria; Keo, Teeda \& McCarty, Paulette (2012). The use of social media: An exploratory study of usage among digital natives. Journal of Public Affairs 12:2, 127-136.

Wrench, Jason (2013). Workplace Communication for the 21st Century: Tools and Strategies that Impact the Bottom Line. Santa Barbara, California: ABC-CLIO.

Youell, David \& Downey, Paula (2000). Communication in a new world order. Strategic Communication Management 4:2, 28-32.

Youn, Seounmi \& Hall, Kimberly (2008). Gender and online privacy among teens: Risk perception, privacy concerns, and protection behaviors. CyberPsychology Q Behavior 11:6, 763-765. 